\title{
ESTIMATION OF AN AIRFOIL DRAG AT HIGH ANGLES OF ATTACK FROM PIV DATA
}

\author{
Austin M. Karr \\ The Ohio State University 201 W 19th Ave, Columbus, OH, United States \\ karr.64@osu.edu \\ Wit Stryczniewicz \\ Aerodynamics Department, Institute of Aviation, Krakowska 110/114, 02-256 Warsaw, Poland \\ wit.stryczniewicz@ilot.edu.pl
}

\begin{abstract}
The paper presents application of Particle Image Velocimetry for determination of an airfoil's drag coefficient in wind tunnel tests. The purpose of the study was to investigate the feasibility of using PIV as an alternative to pressure rake measurements, especially at high angles of attack. The integral momentum concept was applied for determination of fluid drag from experimental low speed wind tunnel data. The drag coefficient was calculated from velocity and pressure rake data for intermediate angles of attack from $5^{\circ}$ to $10^{\circ}$. Additionally, the experimental results were compared to panel method results. After validating the procedures at low angles of attack, the drag coefficient was calculated at close to critical angles of attack. The presented study proved that PIV technique can be considered as an attractive alternative for drag coefficient determination of an airfoil.
\end{abstract}

Keywords: fluid drag, wind tunnel tests, high angles of attack, Particle Image Velocimetry.

\section{INTRODUCTION}

Currently, optical techniques have been more extensively used in wind tunnel testing for the determination of pressure distribution [1], aerodynamic loads [2] of whole models and its individual components, or deformations and displacements [3]. The non-intrusive characteristics of the measurement make optical techniques particularly suitable for investigation of aerodynamic loads in cases where pressure or strain-gage measurements are not possible i.e. living organism investigation [4] [5]. The force balance is not a very accurate measurement technique at low Reynolds number due to small loads, or in cases where flow control is applied, due to wires and cables powering the actuators. Therefore, optical techniques like Particle Image Velocimetry or Pressure Sensitive Paints have now gained attention as methods for determination of aerodynamic loads of whole models and individual parts of wind tunnel models. 
Typically, in cases where aerodynamic balance cannot be applied in wind tunnel tests, determination of the drag is performed by wake analysis with the use a of pressure rake. The methodology of the data reduction requires that the entire wake and freestream region be encompassed within the pressure rake dimensions. This can be easily fulfilled at low angles of attack where the decreased momentum region does not greatly exceed the airfoil thickness. Unfortunately, for high angles of attack the wake can be wider than the pressure rake. Moreover, in order to achieve high accuracy in the drag determination, high spatial resolution of the pressure measurement points is required. In the cases of high angle of attack studies or investigations of airfoils with high-lift surfaces (flaps, slots) there is a necessity for long rakes with large number of total pressure measurement points and usage of multiple multichannel pressure scanners. An alternative approach is to calculate the loss of momentum from velocity data. The Particle Image Velocimetry technique provides high resolution instantaneous velocity fields. This makes the PIV data suitable for determination of aerodynamic loads by use of the integral momentum concept to compute the aerodynamic forces [6]. Although the feasibility of application of the pressure rake analysis for determination of drag at low angles of attack was shown [7][8], the feasibility of the application for high angles of attack was not investigated.

In this paper we present a feasibility study of PIV technique application for drag coefficient determination of an airfoil at angles near the critical AoA. The flow field downstream of an airfoil was investigated in a low speed wind tunnel by PIV and pressure rake analyses. The drag coefficient for low AoA was determined from pressure and velocity data and the drag coefficients for high angles of attack were determined by velocity data.

\section{MATERIALS AND METHODS}

In presented studies, a low speed wind tunnel was used to complete these experiments [9]. Pressure rake and Particle Image Velocimetry [10] techniques were used for determination of an airfoil's drag by wake survey at intermediate angles of attack: $5^{\circ}, 6^{\circ}, 7^{\circ}$ and $10^{\circ}$. The experimental setup allowed for simultaneous measurements of momentum loss in the wake by PIV and pressure rake. The pressure and velocity data were used for determination of drag coefficients by use of the integral momentum concept. Due to large width of the wake at high angles of attack $\left(>30^{\circ}\right)$ the pressure rake was not applicable. Therefore, drag calculated at angles close to airfoil's critical angle of attack were only determined by the PIV method. The experimental data was compared with panel method results.

\subsection{Data reduction}

The drag coefficient was calculated from pressures collected by the pressure rake and the velocities measured by PIV. The data reduction procedure is described below. Additionally, theoretical calculations using the panel method were performed using open access software.

The pressure rake contained 32 pressure sensors, 26 collected the total pressure and 6 collected the static pressure. From the obtained data, the static pressure was averaged and used to calculate the dynamic pressure using equation 1 below:

$$
q=P_{0}-P
$$

where $P_{0}$ is the total pressure, $P$ is the average static pressure, and $q$ is the dynamic pressure. 
The freestream dynamic pressure was calculated using equation 2 below,

$$
q_{\infty}=0.5 \cdot \rho \cdot V_{\infty}^{2}
$$

where $q_{\infty}$ is the freestream dynamic pressure, $\rho$ is the density, and $V_{\infty}$ is the freestream velocity. Equation 3 below [9] was used to calculate the drag coefficient from the dynamic pressures. MATLAB was used to compute the integration. The trapz function was used by approximating the region under the curve as a trapezoid. The calculation of the total area is the drag coefficient,

$$
C_{d}=2 \int\left(\sqrt{\frac{q}{q_{\infty}}}-\frac{q}{q_{\infty}}\right) \frac{d y}{c}
$$

where $y$ is the spanwise wake coordinate and $c$ is the airfoil chord.

The integration bounds were determined by finding the minimum point in the wake profile, then finding the maximum points on each side of the minimum. The two maximum points were used as the bounds of integration. This technique was used to nullify invalid areas of the wake profile that would otherwise distort the results. The drag coefficients were calculated for each time instance then averaged to find the drag coefficient for the airfoil.

The second method involved using the Particle Image Velocimetry technique to obtain velocity profiles of the wake. An adaptive PIV [11] algorithm was used to obtain the instantaneous velocity fields from raw particle data. The velocity vector fields were created from a post-processing PIV program and used to determine the momentum loss in the wake. A virtual line, perpendicular to the wake, was created and used to select the velocity vectors that would be analyzed. This method is comparable to using a pressure wake, except the virtual line measures velocity data instead of pressure data. After selecting the velocity vectors across the wake, the loss of momentum $D$ was calculated using equation 4 below,

$$
D=\rho \int U\left(U_{\infty}-U\right) d S
$$

where $\mathrm{U}$ is the local velocity and $U_{\infty}$ is the freestream velocity. The bounds of integration were determined using the method previously described. After the drag was calculated, the drag coefficient was found using equation 5 below which is a variation of the drag equation.

$$
C_{d}=\frac{2 D}{\rho \cdot V_{\infty}^{2}}
$$

The third method involved using a 2D panel method to calculate theoretical data for comparison and validation. XFLR5 [12] was used to complete the computations. The airfoil coordinates, air density, freestream velocity, and Reynolds number were all inputted into the program which yielded the theoretical drag at various angles of attack. The theoretical data, provided good benchmarking data which was similar to the results obtained.

\subsection{Experimental setup}

The investigation was performed in a T-1 wind tunnel at the Institute of Aviation in Warsaw. It is a closed circuit, open test section wind tunnel, powered by a $55 \mathrm{~kW}$ electric motor and a 4-blade constant-speed fan. Test section diameter is $1.50 \mathrm{~m}$. The maximum airflow velocity in this wind tunnel is $40 \mathrm{~m} / \mathrm{s}$ and the minimum steady velocity of the air-flow is about $11 \mathrm{~m} / \mathrm{s}$. The ILM200 airfoil 
which had a relative thickness of $20 \%$ was used in the investigations. The chord was $0,5 \mathrm{~m}$ and the span of the segment was $1 \mathrm{~m}$. The experimental setup is presented in Figure 1.

The pressures were acquired with the use of an ESP scanner of the DTC Initium system. The measurement range of the scanner was up to $2500 \mathrm{~Pa}\left(10 " \mathrm{H}_{2} \mathrm{O}\right)$. The measurement frequency of the system was $331 \mathrm{~Hz}$. There was 32 pressure measurement points on the rake with $4 \mathrm{~mm}$ spacing in the middle section of 26 points, increasing spacing from 8 through 12, and $20 \mathrm{~mm}$ in the outer sections.

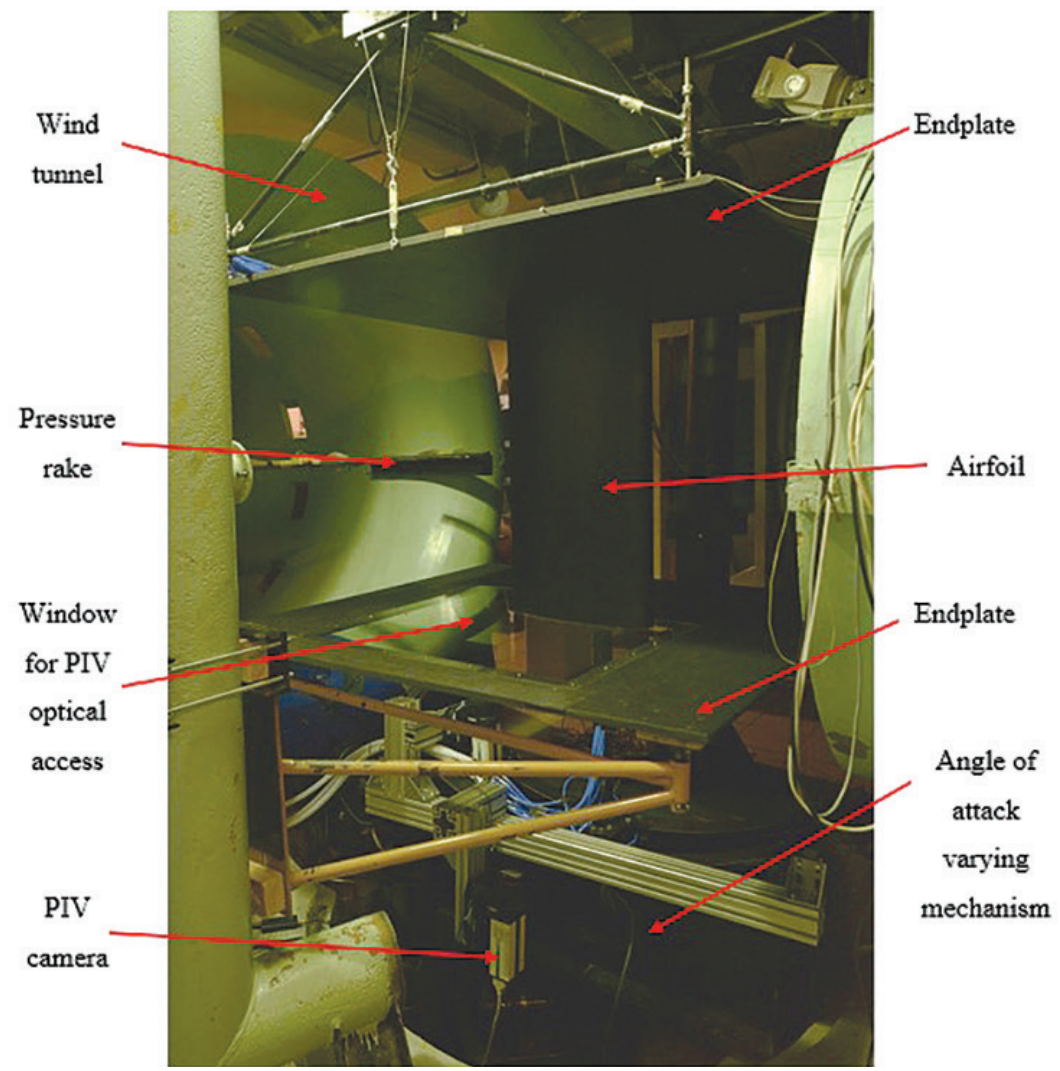

Fig. 1. Experimental setup.

The PIV system consisted of a dual-cavity, solid-state, (Nd:YAG) pulse laser and 4 MP digital camera. The Canon EF $85 \mathrm{~mm}$ f 1:1.2 lenses were used. The lightsheet was formed by a set of cylindrical lenses. The seeding was produced by a seeding generator from DEHC oil. The temporal resolution of the measurements was set to the maximum value of $7 \mathrm{~Hz}$. In order to measure velocities in a range $1 \mathrm{~m} / \mathrm{s}$ to $50 \mathrm{~m} / \mathrm{s}$, the time delay between illumination pulses was set to $70 \mu$ s. Multiple measurements $(>80)$ were taken at each investigated angle of attack. An instantaneous velocity field of the wake of the airfoil at an angle of attack $5^{\circ}$ is presented in Figure 2. A velocity field downstream of the trailing edge at an angle of attack $31^{\circ}$ is presented in Figure 3. 


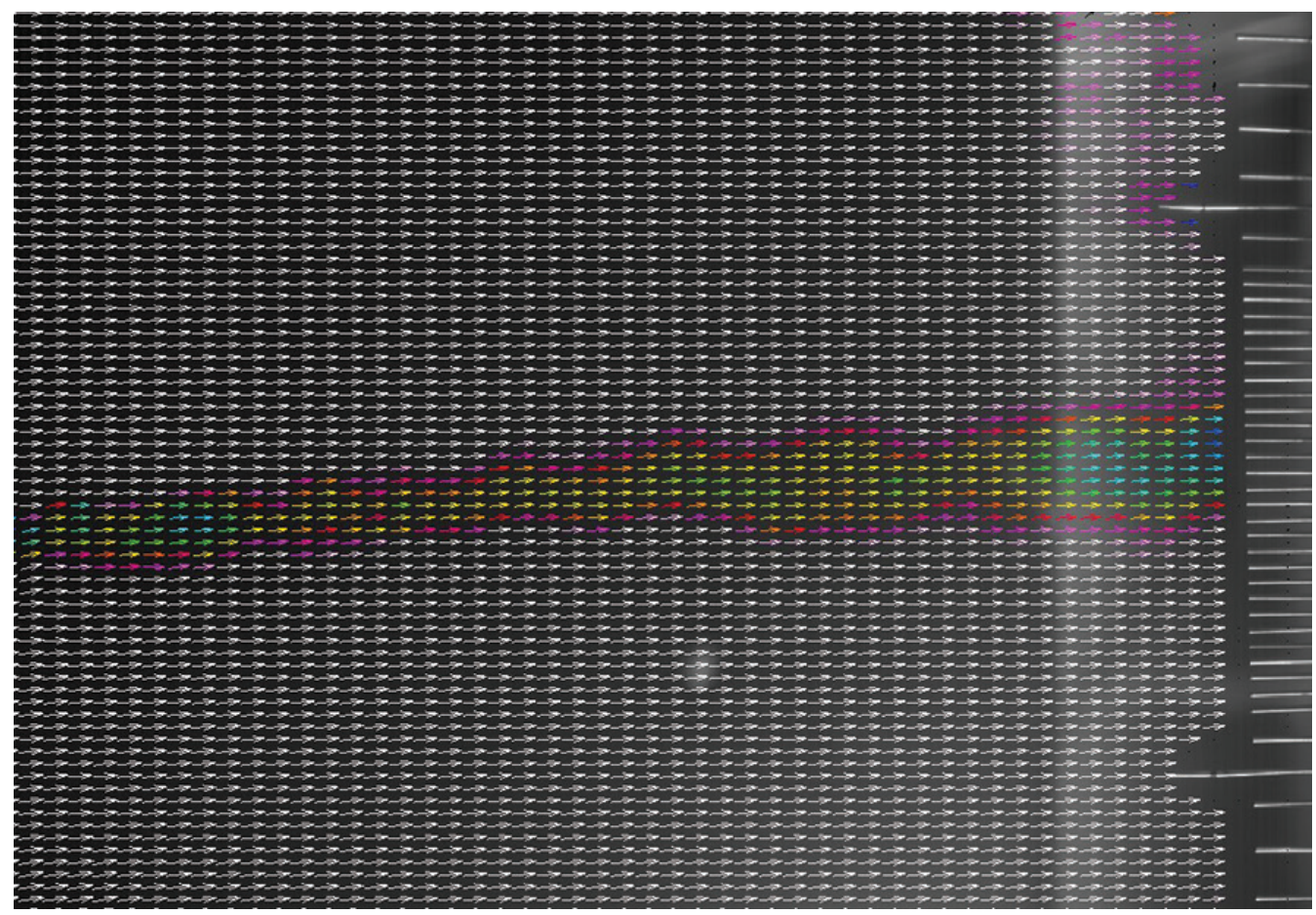

Fig. 2. Instantaneous velocity field measured downstream of the trailing edge at angle of attack $5^{\circ}$. The pressure rake is visible on the right side of the image. Position of the virtual PIV rake is marked with red dotted line.

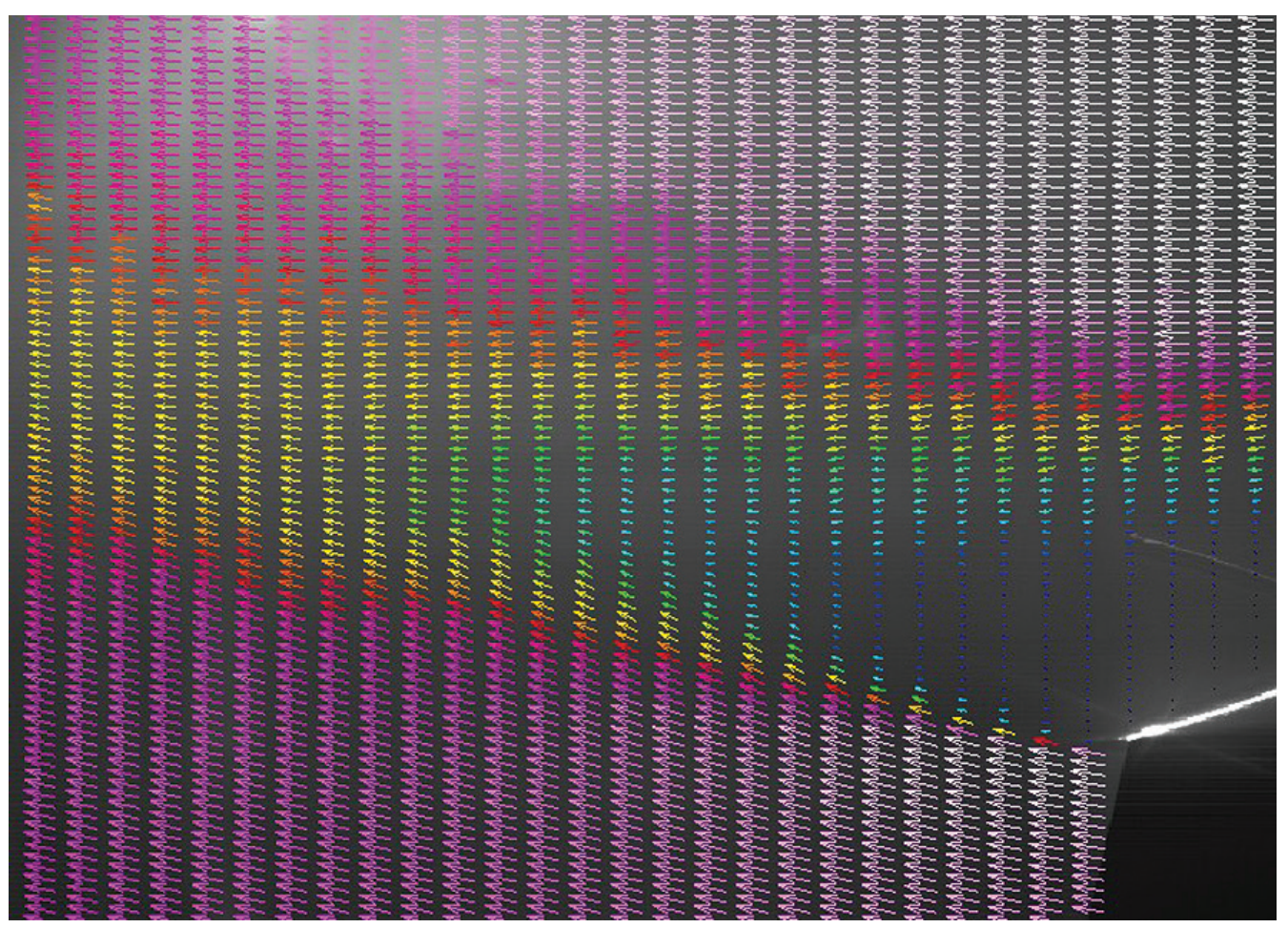

Fig. 3. Velocity field measured downstream of the trailing edge at angle of attack $31^{\circ}$. The vectors are averaged from 10 second acquisition with $7 \mathrm{~Hz}$ repetition. 


\section{RESULTS}

The results obtained from the three different methods all yielded similar results. Figures 4, 5, and 6 show the average wake profiles at various angles of attack. One can notice that the PIV data has a higher resolution.

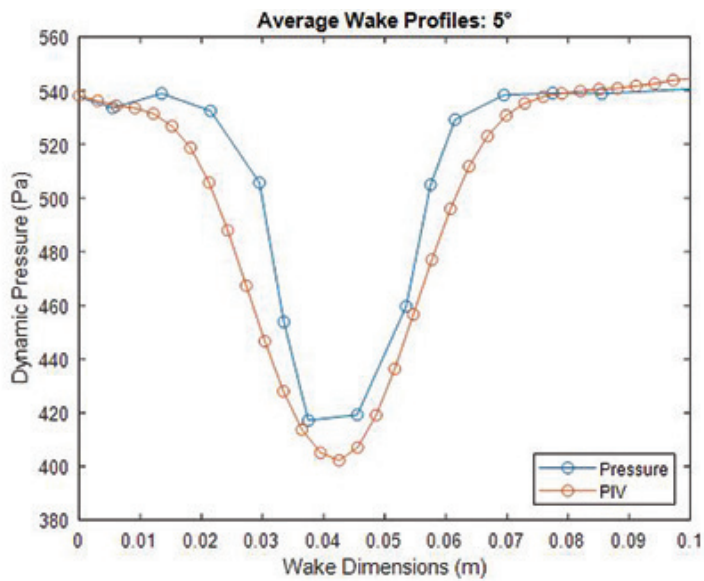

Fig. 4. Average wake profiles from PIV and pressure rake for $\mathrm{AoA}=5^{\circ}$

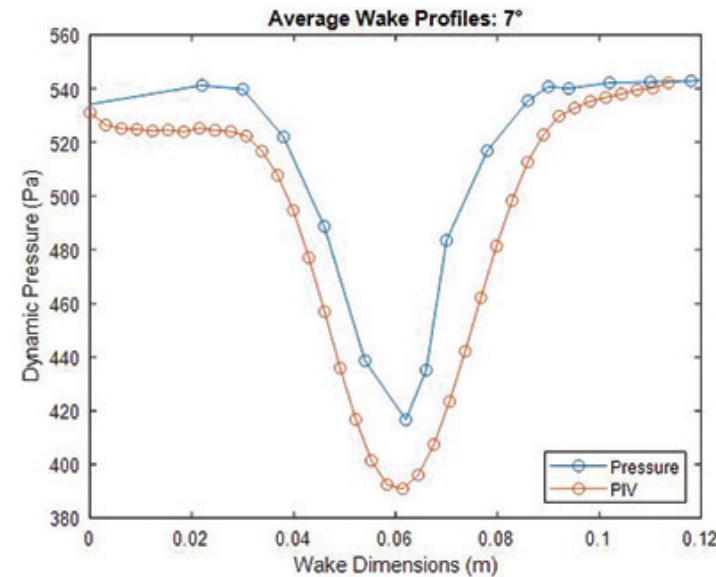

Fig. 5. Average wake profiles from PIV and pressure rake for $\mathrm{AoA}=7^{\circ}$

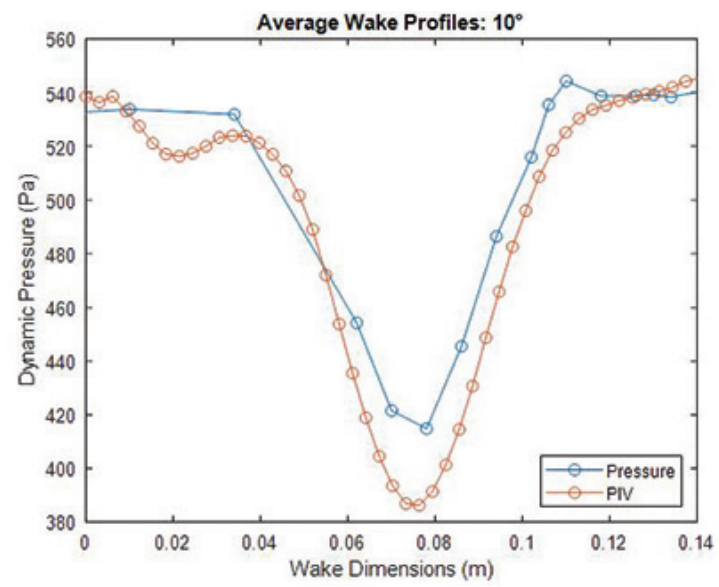

Fig. 6. Average wake profiles from PIV and pressure rake for $\mathrm{AoA}=10^{\circ}$

Figure 7 below shows the drag coefficients for low angles of attack calculated using the three different methods: PIV, pressure rake, and the theoretical panel method. 


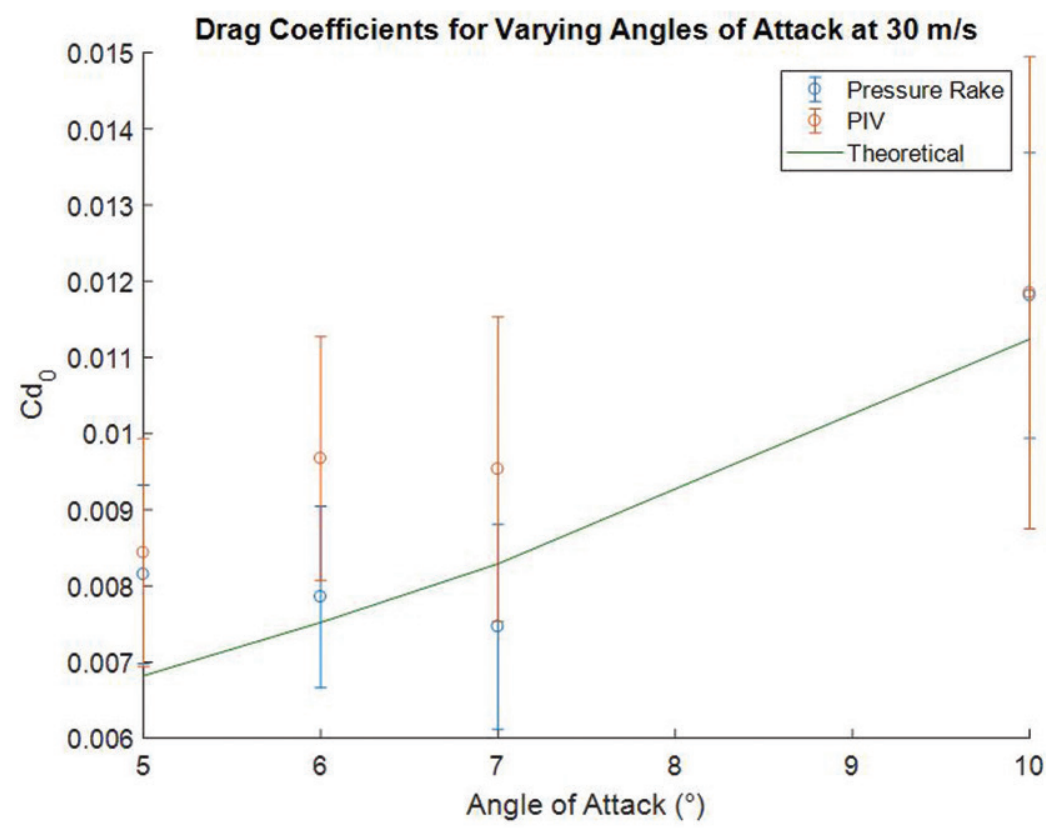

Fig. 7. Drag coefficients for low angles of attack

The pressure drop in the wakes at high angles of attack are presented in Figure 8. The drag coefficients calculated for low and high angles of attack are presented in Figure 9. One can notice that as the angle of attack increases, the uncertainty also increases. This is caused by large fluctuations of the pressure in the wake at close to critical angles of attack before full separation (airfoil stall).

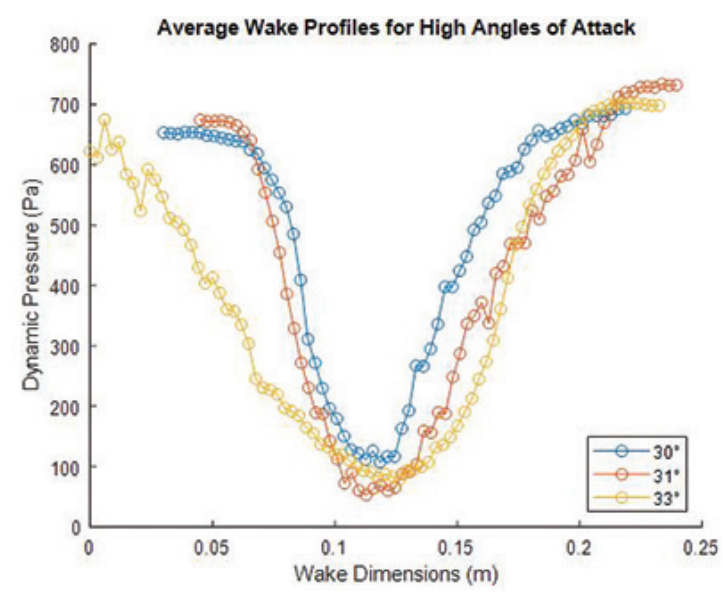

Fig. 8. Average wake profiles from PIV for high angles of attack 


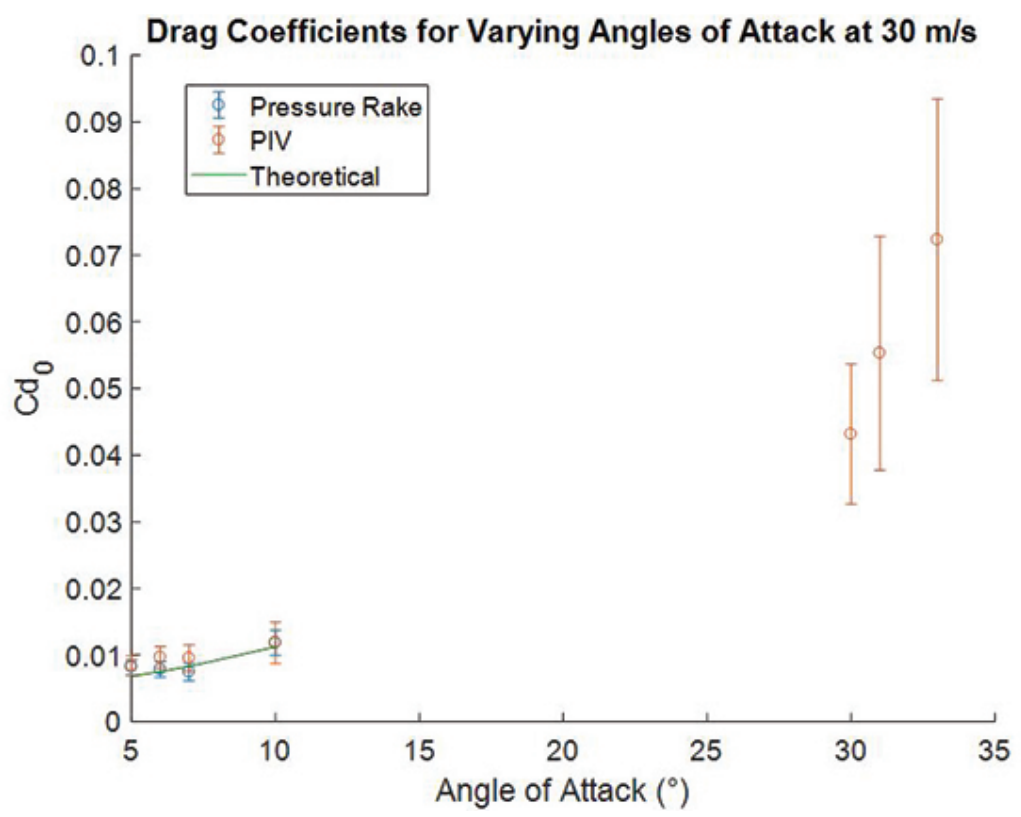

Fig. 9. Drag coefficient for low and high angles of attack

\section{CONCLUSIONS}

Particle Image Velocimetry measurements are an attractive alternative to a conventional pressure rake because of its noninvasiveness. PIV is a very versatile technique because of its ability to be used in a wide range of environments, even those that include very large or very small test areas. For example, an airfoil at a high angle of attack produces a very large wake that a pressure rake may not be able to accommodate, so the PIV technique is an appealing solution.

In the presented paper, the average wake profiles and drag coefficients were compared using PIV and a pressure rake at low angles of attack. The wake profiles were nearly identical, except the pressure wakes were slightly shifted upwards. The momentum loss, measured by both PIV and the pressure rake, was used for calculation of the airfoil's drag coefficients at intermediate angles of attack. The panel method was used to validate the results obtained by the pressure rake and PIV. After validating the PIV method for intermediate angles of attack, the developed procedure was used to analyze wakes at high angles of attack.

\section{REFERENCES}

[1] Jeon Y. J., Earl T., Braud P., Chatellier L., David L., 2016, “3D Pressure Field around an Inclined Airfoil by Tomographic TR-PIV and Its Comparison with Direct Pressure Measurements", $18^{\text {th }}$ International Symposium on the Application of Laser and Imaging Techniques to Fluid Mechanic, Lisbon, Portugal.

[2] Oudheusden B.W. van, Scarano F., Roosenboom E.W.M., Casimiri E.W.F., Souverein L.J., 2007, "Evaluation of integral forces and pressure fields from planar velocity data for incompressible and compressible flows", Experiments in Fluids, 43, pp. 153-162. 
[3] Pan B. and Li K., 2011, "A fast digital image correlation method for deformation measurement", Optics and Lasers in Engineering, 49, pp. 841-847.

[4] Terra W., Sciacchitano A., Scarano F., 2015, "Large-scale tomo-PIV for on-site drag analysis in speed sports", Workshop on Non-Intrusive Measurements for unsteady flows and aerodynamics, Delft, the Netherlands.

[5] Terra W., Sciacchitano A., Scarano F., Oudheusden B.W. van, 2018, Drag resolution of a PIV wake rake for transiting models, Experiments in Fluids 59.

[6] Oudheusden B.W. van, Scarano F., Casimiri E.W.F., 2006, "Non-intrusive load characterization of an airfoil using PIV", Experiments in Fluids 40, pp. 988-922.

[7] Ashok A, Ragni D, Oudheusden BW van, Scarano F, PIV-based surface pressure and aerodynamic loads determination on a transonic airfoil, EWA International workshop, Delft, The Netherlands, 31.03-01.04.2008.

[8] Albrecht T., Campo V. del, Weier T., Gerbeth G., 2012, Comparision of PIV-based Methods for Airfoil Loads Evaluation, 16 Int Symposium of Laser Techniques to Fluid Flow Mechanics, Lisbon, Portugal.

[9] Rae WH and Pope A, "Low-Speed Wind Tunnel Testing”, John Wiley \& Sons, 1984.

[10] Raffel M, Willert CE, Werely ST, Kompenhans J, "Particle Image Velocimetry: A Practical Guide”, Springer, 2007.

[11] Theunissen R., Scarano F., Riethmuller M.L., (2007), "An adaptive sampling and windowing interrogation method in PIV", Measurement Science and Technology, 18, 275.

[12] http://www.xflr5.htm

\section{WYZNACZANIE OPORU PROFILU LOTNICZEGO DLA DUŻYCH KĄTÓW NATARCIA Z DANYCH POMIAROWYCH UZYSKANYCH METODĄ ANEMOMETRII OBRAZOWEJ}

\section{Streszczenie}

W artykule przedstawiono zastosowanie metody anemometrii obrazowej (PIV) do wyznaczenia współczynnika oporu profilu lotniczego. Celem badań było sprawdzenie możliwości zastosowania metody PIV jako alternatywy do pomiarów ciśnieniowych za pomocą sondy grzebieniowej, w szczególności dla dużych kątów natarcia. Opór profilu wyznaczono poprzez określenie straty pędu w śladzie z danych uzyskanych w eksperymentalnych badaniach tunelowych. Współczynnik oporu wyznaczono dla katów natarcia od $5^{\circ}$ do $10^{\circ}$ przy wykorzystaniu danych ciśnieniowych oraz prędkości uzyskanych metodą anemometrii obrazowej. Dodatkowo wyniki uzyskane z danych eksperymentalnych porównano z wynikami uznanymi metodą panelową. Po walidacji procedur dla średnich katów natarcia metodykę zastosowano do wyznaczenia współczynników oporu dla kątów natarcia bliskich krytycznemu kątowi natarcia profilu. Przedstawione badania potwierdziły skuteczność zastosowania metody anemometrii obrazowej, jako alternatywy pomiarów ciśnieniowych, do wyznaczenia oporu profilu lotniczego w badaniach tunelowych.

Słowa kluczowe: opór aerodynamiczny, badania tunelowe, anemometria obrazowa. 